\title{
Modification of Remdesivir as a Better Inhibitor of COVID-19: A Computational Docking Study
}

\author{
Mita Shikder ${ }^{1}$, Kazi Ahsan Ahmed ${ }^{1}$, Tasnin Al Hasib ${ }^{1}$, Md. Lutful Kabir ${ }^{1 *}$ \\ ${ }^{1}$ Department of Biochemistry and Molecular Biology, Bangabandhu Sheikh Mujibur Rahman Science and \\ Technology University, Gopalganj- 8100, Bangladesh
}

*Corresponding author: Md. Lutful Kabir; kabir.bmb@bsmrstu.edu.bd

\begin{abstract}
Coronavirus (COVID-19) mediated infection is a highly contagious respiratory illness that was initially found in Wuhan city of Hubei Province in China. The ongoing pandemic of the novel SARS-CoV-2 virus is affecting global health. Despite the recent success in vaccination on a trial basis, there is no treatment of the infection. Thus, establishing an effective therapeutic measure is of apex priority among biologists and healthcare professionals. Re-purposing Remdesivir, a broad-spectrum antiviral agent that inhibits viral RNA polymerase, has been found effective for the treatment of COVID-19. In this study, modification of the existing drug Remdesivir was done. In logical drug designing and development, molecular recognition plays a central role in this sphere. The anti viral function of Remdesivir is achieved by binding to RNA polymerase enzyme. The protein 7BTF is an RNA-dependent RNA polymerase that plays a crucial role in coronavirus replication and transcription machinery and it appears to be the primary target of the antiviral drug Remdesivir. The study intend to design derivative compounds form Remdesivir to screen out the a better drug against the SARS-CoV-2 virus by inhibiting the targeted protein. The efficacy of these new drugs was also tested by molecular docking calculations. The drug derivatives were docked for binding affinity and non-bond interactions. Pharmacokinetic activities of the designed drugs are also predicted. All the drugs are non-carcinogenic and chemically reactive. In our study, modified compound D-I has exhibited the best performance among Remdesivir and it's derivatives. This study might provide an insight into the potential of a Remdesivir derivative in treating SARS-CoV-2 infection.
\end{abstract}

Keywords: COVID-19, Remdesivir, Molecular Docking, SARS-CoV-2.

\section{Introduction}

The coronavirus disease 2019 (COVID-19) pandemic began in late December 2019 in Wuhan, the capital of Central China's Hubei Province. Since then, it has spread rapidly to China and other countries ${ }^{1}$. Severe Acute Respiratory Syndrome Coronavirus 2 can affect both animals and humans. It can affect respiratory, gastrointestinal, hepatic, and some other systems ${ }^{2}$. The Covid-19 virus spreads through saliva, droplets, or secretions from an infected person's nose after coughing, sneezing, yawning even while speaking ${ }^{3}$. A wide variety of fatal complications observed in SARS-CoV-2 infected patients including acute respiratory illness, multi system organ failure, and eventual death. Elderly patients and those with pre-existing respiratory or cardiovascular complications are at the highest risk ${ }^{4}$. The SARS-Cov-2 is a pathogen that poses a serious threat to global public health ${ }^{5}$.

Proper vaccination of the novel coronavirus in humans cannot be established effectively because of large genetic variations and frequent recombination of their genome ${ }^{6}$. Coronavirus consists of a positive sense single-stranded RNA genome ${ }^{7}$. The coronavirus virus has a nucleocapsid core that contains a spike (S) 
protein, a membrane (M) protein, and an envelope (E) protein. The RNA is packaged via the nucleocapsid (N) protein into a helical nucleocapsid ${ }^{8}$. Protein 7BTF is an RNA-dependent RNA polymerase that is a vital component of coronavirus replication and transcription machinery and is seen as the primary target of the antiviral drugs ${ }^{9}$. A worsening epidemic of the SARS-CoV-2 virus is affecting global health and effective treatment options are urgently needed ${ }^{10}$. Although there is no particular drug available currently, Drug discovery and development may be the solution to control the outbreak.

However, most approved drugs and trial agents have shown antiviral activity against SARS-CoV-2 invitro. Remdesivir (also GS-5734) is a potential drug candidate for coronaviruses which is a monophosphoramidate prodrug of an adenosine analogue ${ }^{11}$. It was synthesized and developed by Gilead Sciences as a treatment for Ebola virus infection ${ }^{12}$. Remdesivir is an effective inhibitor of SARS-CoV-2 replication in human nasal and bronchial airway epithelial cells ${ }^{13}$. Studies show that, Remdesivir inhibit the target protein 7BTF that catalyzes viral RNA synthesis of COVID-19 ${ }^{14}$.

This study deals with the improvement of the drug efficacy of Remdesivir using the computational method of drug design. Several factors such as molecular recognition, binding affinity, and interactions ae calculated in computational drug designing and development. Molecular recognition plays a vital role in applications such as chemical catalysts, treatment, and sensor design ${ }^{15}$. Binding affinity and interactions are two main factors that help to understand the molecular recognition in drug-receptor complexes and are important for structure-based drug design in medicinal chemistry ${ }^{16}$. To estimate the binding affinity and nonbond interactions between designed molecules and the receptor protein, molecular docking analysis was performed ${ }^{17}$. Molecular docking is performed to predict the binding mode (s) of protein ligands for ligand-protein docking ${ }^{18}$. We have designed several new Remdesivir derivatives including D-CF 3 , D$\mathrm{C}_{2} \mathrm{H}_{5}$, D-F, D-I, D- $\mathrm{CH}_{3}, \mathrm{D}-\mathrm{OH}$. Among them, the new drug compound D-I shows strong binding and nonbond interactions with the target molecule than Remdesivir. The D-I derivative shows more promise in the inhibition of SARS-CoV-2.

\section{Computational Methodology}

\subsection{Ligands Preparation}

The 3D structure of Remdesivir was derived from PubChem online database in SDF file ${ }^{19}$. Remdesivir was structurally manipulated with $-\mathrm{C}_{2} \mathrm{H}_{5},-\mathrm{CF}_{3},-\mathrm{CH}_{3}$, -F, -I, -OH functional groups by replacing $-\mathrm{NH}_{2}$ group at C-26 position. These modified compounds were marked as $\mathrm{D}_{2} \mathrm{C}_{2} \mathrm{H}_{5}, \mathrm{D}-\mathrm{CF}_{3}, \mathrm{D}-\mathrm{CH}_{3}$, D-F, D-I, D$\mathrm{OH}$. Energy minimization of the ligands and its derivatives were obtained by using chem3D pro software. The minimized structure of all the ligands was stored as SDF format for further analysis. Threedimensional structure of the parent drug and its derivatives were illustrated in figure 1.

Figure 1: two dimensional (2D) structure of Remdesivir and its derivatives were shown below: 


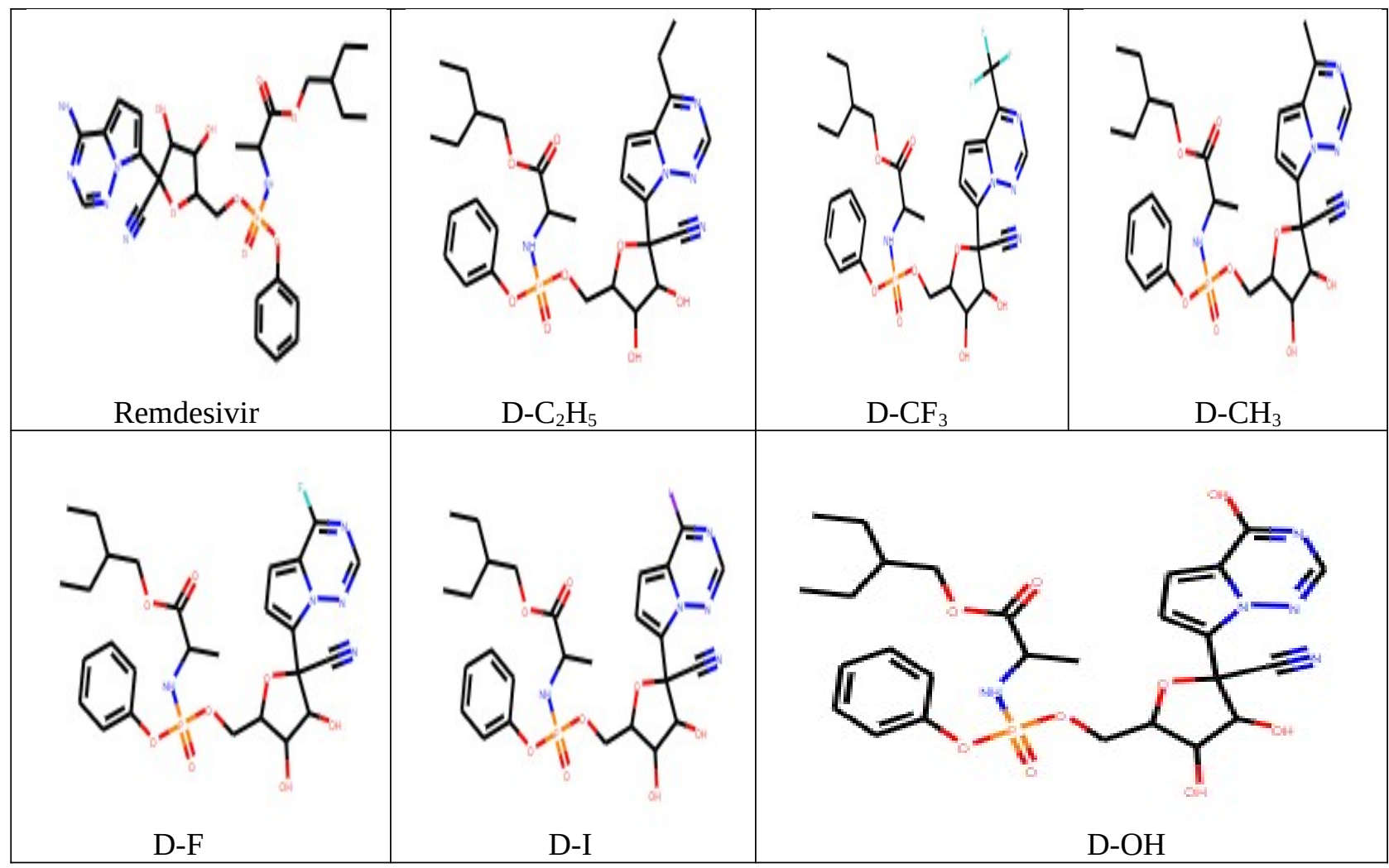

\subsection{Target Preparation for Docking}

Remdesivir and its derivatives were subjected to docking analysis against SARS-CoV-2 RNA-dependent RNA polymerase (In PDB ID: 7BTF). The structure of 7BTF was retrieved from Protein Data Bank online database in PDB format ${ }^{20}$. In our study, a chain of targeted protein was considered for molecular docking analysis. By using PYMOL software, unwanted ions, ligands, functional groups, water molecules were removed from protein structure ${ }^{21}$. Energy minimization of optimized protein structure was carried out with Swiss-PDB Viewer and saved as PDB format ${ }^{22}$. The optimized protein structure was shown in figure 2.

Figure 2: Optimized structure of protein code 7BTF was obtained from PYMOL software.

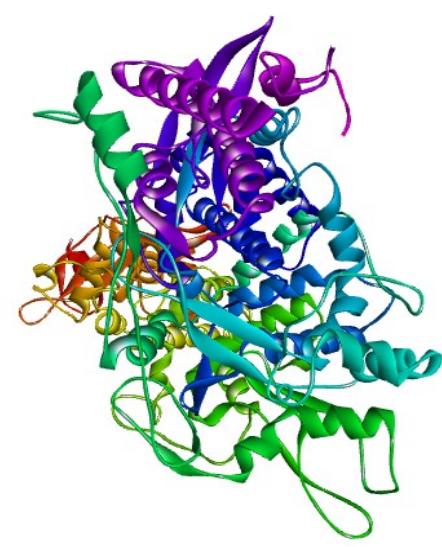




\subsection{Study of Molecular Docking and Non-bond Interaction}

Molecular docking plays a significant role in computer aided drug designing that predicts the binding energy of drugs with target protein molecule ${ }^{23}$. After successful docking, it finds out the highdimensional spaces, and based on scoring it gives the best candidate from libraries of compounds and proposes the hypothesis of how that ligand inhibits the target protein ${ }^{24}$. In this study, molecular docking was carried out for Remdesivir and its derivatives against 7BTF using autodock vina wizard under PYRX software to screen out the potential drug with lowest binding affinity ${ }^{25}$. The maximum negative binding affinity was considered as the best ligand-receptor complex. The docked molecules were visualized in biovia discovery studio visualizer for displaying the binding site and non-bond interactions of drugprotein complex ${ }^{26}$. The identification and quantification of these non-bond interactions are very useful for the structure-based drug design in structural biology and pharmaceuticals chemistry ${ }^{27}$.

\subsection{Pharmacokinetic Parameter Study}

The Pharmacokinetic properties of Remdesivir and its modifiers were evaluated to estimate the suitability and efficacy of them for 7BTF protein molecule. AdmetSAR new version online database and MedChem Designer software were utilized to screen out pharmacokinetic activity related to drug absorption, distribution, metabolism, excretion, and toxicity(ADMET) for Remdesivir and its derivatives ${ }^{28}$. The process of Pharmacokinetic Parameter analysis was done by using SDF and SMILES files of the compounds.

\section{Result and Discussion}

\subsection{Analysis of Binding affinity and Non-bond Interaction}

Remdesivir was used as a parent drug. D-I was one of the modified drugs where the iodine group was added to position 26C of Remdesivir by replacing $-\mathrm{NH}_{2}$ group. Iodine plays an important role in the production of thyroid hormone in all vertebrates ${ }^{29}$. D-I interacts with the protein code 7BTF and shows the most potent activity. D-I also predicts the strongest binding affinity and promising hydrogen and hydrophobic bond with 7BTF. In this study, we found significant pharmacokinetic properties, binding affinity, and non-bond interaction for D-I, D-OH, D- $\mathrm{CF}_{3}$ compared to the parent drug. In modified drug $\mathrm{D}-\mathrm{CF}_{3}$, trifluoromethyl group ( $-\mathrm{CF}_{3}$ ) was also added to position $26 \mathrm{C}$ of the parent drug by replacing $-\mathrm{NH}_{2}$ group. Trifluoromethyl group can be integrated with various organic molecules and mostly used in the chemicals and pharmaceuticals sector ${ }^{30,31}$. Trifluoromethyl group also shows hydrophobicity and high electronegativity characteristics that are effective in drug development to make better pharmacological activity $^{32}$. Modified compound D-CF ${ }_{3}$ represents halogen bonds with target protein that were absent in Remdesivir. Many literatures suggested that halogen bonds play a significant role in structural and chemical biology which may effective in drug design ${ }^{33}$.

Table 1: Binding energy and Non-bond interactions of Remdesivir and its derivatives against 7BTF protein generated via flexible docking.

\begin{tabular}{lllll}
\hline Compounds & $\begin{array}{l}\text { Binding } \\
\text { Energy } \\
\text { Of Protein }\end{array}$ & $\begin{array}{l}\text { Hydrogen bonds } \\
\text { (Amino acid .... Ligands) } \\
\text { Distance }(\AA)\end{array}$ & $\begin{array}{l}\text { Hydrophobic Bonds } \\
\text { (Amino acid ..... } \\
\text { Ligands) } \\
\text { Distance( }(\mathbf{\AA})\end{array}$ & $\begin{array}{l}\text { Halogen } \\
\text { Bonds } \\
\text { (Amino acid ..... } \\
\text { Ligands) } \\
\text { Distance( }(\AA)\end{array}$ \\
\hline $\begin{array}{l}\text { Remdesivir } \\
\text {-7BTF }\end{array}$ & -8.0 & TYR38(1.90351) & ILE37(3.74012) & \\
complex & & ASP218(2.52094) & PHE35(5.10779) & \\
\hline
\end{tabular}




\begin{tabular}{|c|c|c|c|c|}
\hline & & ASN209(2.77422) & $\begin{array}{l}\text { LYS50(5.14533) } \\
\text { PHE35(4.64985) } \\
\text { PHE48(5.42241) }\end{array}$ & \\
\hline $\begin{array}{l}\text { D-CF } 3^{-} \\
7 B T F \\
\text { complex }\end{array}$ & -8.8 & $\begin{array}{l}\text { ASP36(2.30849) } \\
\text { ASP208(1.77102) } \\
\text { LYS73(2.26438) } \\
\text { THR206(2.30976) } \\
\text { ASN209(2.8617) } \\
\text { ASP208(3.34594) }\end{array}$ & $\begin{array}{l}\text { ILE37(3.99764) } \\
\text { PHE35(4.93455) } \\
\text { PHE48(5.1657) } \\
\text { LYS50(5.07531) } \\
\text { LYS50(5.16584) } \\
\text { PHE35(4.40492) } \\
\text { TYR217(5.27383) }\end{array}$ & $\begin{array}{l}\text { TYR38(3.10373) } \\
\text { TYR38(3.20673) }\end{array}$ \\
\hline $\begin{array}{l}\text { D- } \mathrm{C}_{2} \mathrm{H}_{5^{-}} \\
\text {7BTF } \\
\text { complex }\end{array}$ & -8.2 & $\begin{array}{l}\text { ASP208(1.97511) } \\
\text { LYS73(2.68496) } \\
\text { LYS73(2.79933) }\end{array}$ & $\begin{array}{l}\text { LYS50(4.67692) } \\
\text { LYS50(4.95118) } \\
\text { CYS53(5.37927) } \\
\text { PHE35(4.61804) }\end{array}$ & \\
\hline $\begin{array}{l}\text { D-F-7BTF } \\
\text { complex }\end{array}$ & -7.0 & $\begin{array}{l}\text { ASP36(2.70281) } \\
\text { THR206(2.0049) } \\
\text { ASP218(3.69302) }\end{array}$ & $\begin{array}{l}\text { PHE48(3.66647) } \\
\text { ILE37(4.32884) } \\
\text { LYS50(3.7628) } \\
\text { PHE35(4.69922) } \\
\text { PHE48(4.03955) }\end{array}$ & \\
\hline $\begin{array}{l}\text { D-I -7BTF } \\
\text { complex }\end{array}$ & -9.5 & $\begin{array}{l}\text { ASP218(3.07168) } \\
\text { ASP208(2.16829) } \\
\text { ARG116(2.69372) } \\
\text { ASP218(3.34901) } \\
\text { ASP218(3.52713) } \\
\text { ILE37(3.61632) }\end{array}$ & $\begin{array}{l}\text { PHE35(3.75626) } \\
\text { PHE48(5.47933) } \\
\text { LYS50(4.98055) } \\
\text { CYS53(5.07059) } \\
\text { VAL71(4.47771) } \\
\text { ILE37(5.307) }\end{array}$ & \\
\hline $\begin{array}{l}\text { D-CH } 3^{-} \\
\text {7BTF } \\
\text { complex }\end{array}$ & -8.5 & $\begin{array}{l}\text { ASP36(2.39497) } \\
\text { ASP36(2.19445) } \\
\text { ASP208(2.5368) } \\
\text { TYR38(2.96651) } \\
\text { LYS73(2.73509) } \\
\text { LYS73(2.56063) } \\
\text { THR206(2.15483) } \\
\text { ASP218(3.66615) } \\
\text { ILE37(3.74496) }\end{array}$ & $\begin{array}{l}\text { LYS50(5.42594) } \\
\text { LYS50(5.4304) } \\
\text { PHE35(5.41148) } \\
\text { TYR217(5.24463) } \\
\text { TYR217(5.32875) }\end{array}$ & \\
\hline $\begin{array}{l}\text { D-OH- } \\
\text { 7BTF } \\
\text { complex }\end{array}$ & -8.9 & $\begin{array}{l}\text { ASP218(2.83755) } \\
\text { ASP36(2.29362) } \\
\text { ASP36(2.41227) } \\
\text { ASP208(2.4879) } \\
\text { ASP208(2.51037) } \\
\text { LYS73(2.07675) } \\
\text { ARG116(2.81995) } \\
\text { THR206(2.16358) } \\
\text { ASP218(3.18016) } \\
\text { ASP218(3.40027) }\end{array}$ & $\begin{array}{l}\text { PHE35(3.70824) } \\
\text { CYS53(4.97987) } \\
\text { VAL71(4.1169) } \\
\text { LYS50(5.18185) } \\
\text { LYS50(4.99305) } \\
\text { TYR217(5.33502) }\end{array}$ & \\
\hline
\end{tabular}

Modified compounds D-I, D-CF 3 , D-OH, D- $\mathrm{CH}_{3}$, and D- $\mathrm{C}_{2} \mathrm{H}_{5}$ show increased binding affinity -9.5, -8.8, -8.9, -8.5, and $-8.2 \mathrm{kcal} / \mathrm{mol}$ where $-8.0 \mathrm{kcal} / \mathrm{mol}$ for Remdesivir. These modified drugs also predict significant hydrogen and hydrophobic bonds with target protein that were described in Table 1. A hydrogen bond is essential for DNA structure and indicates that hydrogen bond $<2.3 \AA$ increases the binding affinity by several magnitude ${ }^{34}$ When both the donor and acceptor have either significantly stronger or significantly weaker $\mathrm{H}$-bonding capabilities than the hydrogen and oxygen atoms in water $\mathrm{H}$ bonds boost receptor-ligand interaction. On the contrary, the presence of both the strong and weak $\mathrm{H}$ - 
bond pairings decrease ligand binding affinity due to interference with bulk water ${ }^{35}$. A strong hydrogen bond with ASP208 (2.16829) was found in D-I -7BTF complex.

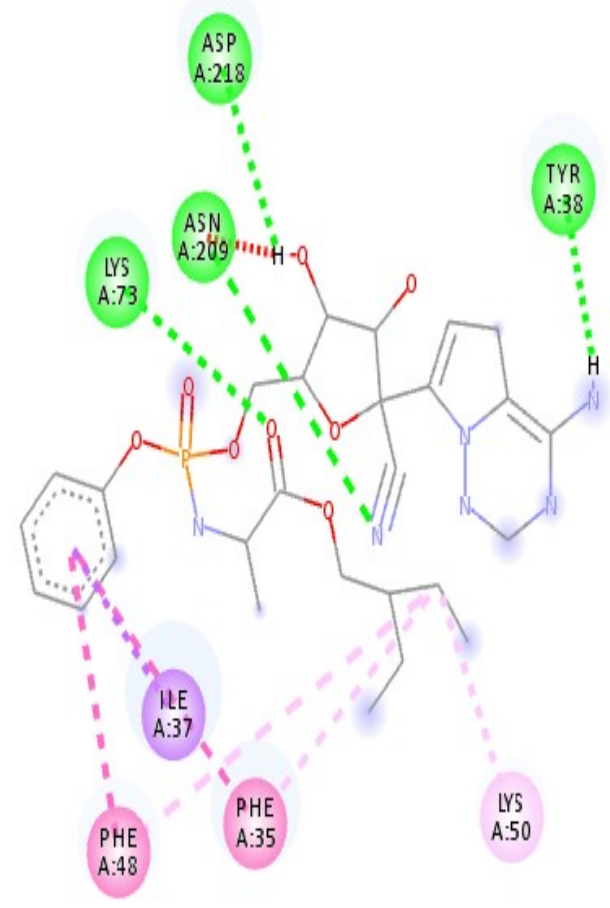

Figure 3: Remdesivir-7BTF interaction

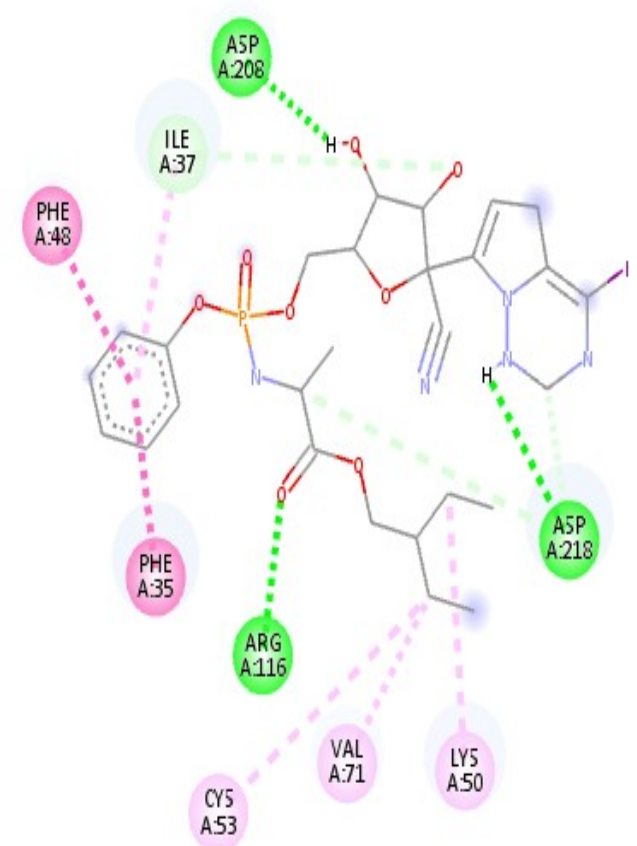

Figure 4: D-I against 7BTF interaction

The strongest hydrogen bond with ASP208(1.77102) and a strong hydrogen bond with LYS73(2.26438) was found in D-CF 3 -7BTF complex. D-OH-7BTF complex also shows promising hydrogen bonds with ASP36(2.29362), LYS73(2.07675), and THR206(2.16358). Modified drug D-CF 3 shows hydrogen, hydrophobic, and halogen bonding interaction by binding with 7BTF. The significant halogen bonds with TYR38(3.10373) and TYR38(3.20673) were observed in D-CF 3 -7BTF complex. Jacob Israelachvili \& Richard Pashley described that hydrophobic interactions decay exponentially with distance and best at 0$100 \AA$ range ${ }^{36}$. Thus all the drugs exhibit promising hydrophobic interaction. 


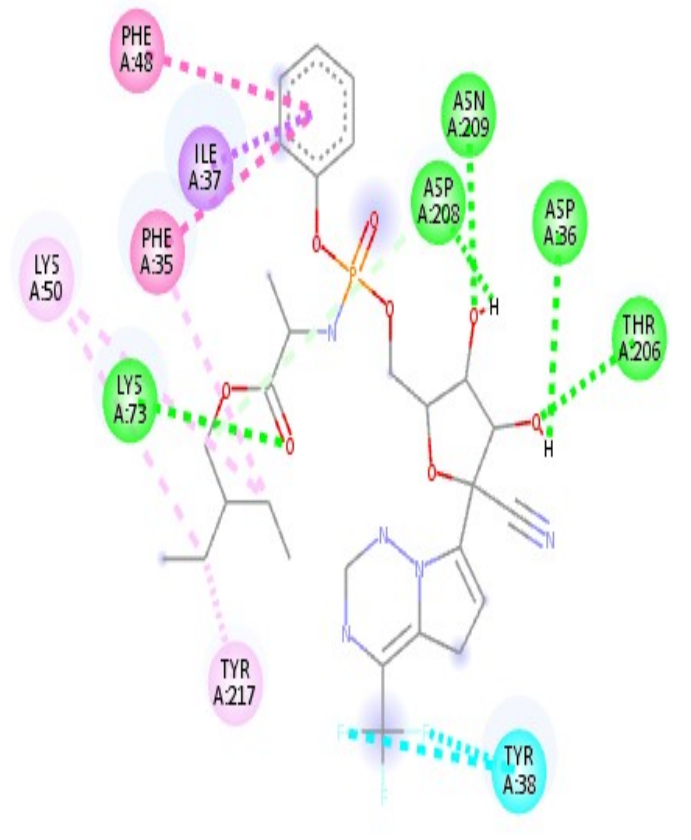

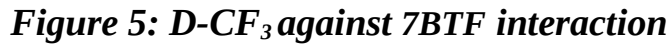

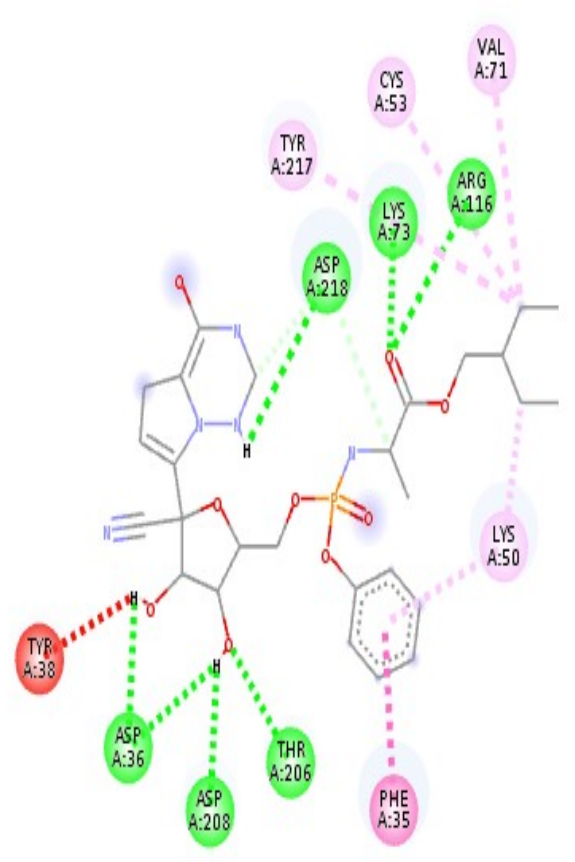

Figure 6: D-OH against 7BTF interaction

\subsection{Analysis of Pharmacokinetic Activity}

Modified drugs show a positive response to the Blood-Brain Barrier (BBB), meaning they can pass through BBB. Positive intestinal absorption scores and negative caco-2 permeability indicate suitable bioavailability ${ }^{37}$. The positive response of human intestinal absorption indicates all the drugs are absorbed by human intestine ${ }^{38}$. Prevention of drug accumulation in brain and proper excretion of drugs can be assured by P- glycoprotein inhibiting score ${ }^{39}$. Inhibition of Human Ether-a-go-go-Related Gene (hERG) by drugs can induce ventricular arrhythmia, in the worst case can cause cardiac death ${ }^{40}$. All the modified drugs are non-carcinogenic, so they can be safely administrated. All the parameters for the calculation of pharmacokinetic activity were obtained from AdmetSAR@LMMD new version and tabulated in Table 2.

Table 2: Selected pharmacokinetic parameters of Remdesivir and its derivatives were obtained by using AdmetSAR new version online database.

\begin{tabular}{|c|c|c|c|c|c|c|}
\hline \multirow[t]{2}{*}{ Compounds } & \multicolumn{6}{|c|}{ Parameters } \\
\hline & $\begin{array}{l}\text { Blood-Brain } \\
\text { Barrier }\end{array}$ & $\begin{array}{l}\text { Human } \\
\text { Intestinal } \\
\text { Absorption }\end{array}$ & $\begin{array}{l}\text { Caco-2 } \\
\text { Permeability }\end{array}$ & $\begin{array}{l}\text { P-glycoprotein } \\
\text { Inhibitor }\end{array}$ & $\begin{array}{l}\text { Human Ether-a- } \\
\text { go-go-Related } \\
\text { Gene Inhibition }\end{array}$ & Carcinogens \\
\hline Remdesivir & $\begin{array}{l}+ \\
0.9625\end{array}$ & $\begin{array}{l}\text { HIA+ } \\
0.9135\end{array}$ & $\begin{array}{l}\text { Caco2- } \\
0.8482\end{array}$ & $\begin{array}{l}+ \\
0.7247\end{array}$ & $\begin{array}{l}- \\
0.5000\end{array}$ & $\begin{array}{l}- \\
0.9714\end{array}$ \\
\hline $\mathrm{D}-\mathrm{CF}_{3}$ & $\begin{array}{l}+ \\
0.9673\end{array}$ & $\begin{array}{l}\text { HIA+ } \\
0.9094\end{array}$ & $\begin{array}{l}\text { Caco2- } \\
0.8451\end{array}$ & $\begin{array}{l}+ \\
0.7398\end{array}$ & $\begin{array}{l}- \\
0.3979\end{array}$ & $\begin{array}{l}- \\
0.9429\end{array}$ \\
\hline D-F & $\begin{array}{l}+ \\
0.9683\end{array}$ & $\begin{array}{l}\text { HIA+ } \\
0.9123\end{array}$ & $\begin{array}{l}\text { Caco2- } \\
0.8479\end{array}$ & $\begin{array}{l}+ \\
0.7196\end{array}$ & $\begin{array}{l}- \\
0.4027\end{array}$ & $\begin{array}{l}- \\
0.9429\end{array}$ \\
\hline D-I & + & HIA+ & Caco2- & + & - & - \\
\hline
\end{tabular}




\begin{tabular}{lllllll} 
& 0.9666 & 0.8743 & 0.8484 & 0.7290 & 0.4115 & 0.9429 \\
$\mathbf{D}-\mathbf{C H}_{3}$ & + & HIA + & Caco2- & + & - & - \\
& 0.9605 & 0.9302 & 0.8440 & 0.7531 & 0.4485 & 0.9714 \\
$\mathbf{D}-\mathbf{O H}$ & + & HIA+ & Caco2- & + & - & - \\
& 0.9567 & 0.9018 & 0.8553 & 0.7176 & 0.5219 & 0.9571 \\
\hline
\end{tabular}

According to MedChem Designer, in generally, lipophilicity is the logarithm value of the partition coefficient P (logP) between octanol and water (buffer), which explains the partition of the unionized (neutral) form of the compound, whereas logD describes the total partition of both the ionized and the unionized forms of the compound ${ }^{41}$. Compounds have logP values more than 5 indicating their lipophilic proprieties, whereas all the compounds in present study showed low logP values less than 5 expressing their hydrophilic nature. It describes the lipophilicity of a compound, which indicates the penetration of the compound from aqueous solutions to lipid-rich zones ${ }^{42}$. According to Lipinski`s rule, the molecular weight should be less than $500 \mathrm{Da}$; $+\log$ and $\mathrm{S}+\log \mathrm{D}$ value should be $<5$ and MlogP values would be lower than 4.15 to penetrate the biological membrane; the number of hydrogen bond donor should also be less than $5^{43,44}$. Moriguchi's $\log \mathrm{P}$ (MLogP) of greater than 4.15 suggests that the compound would be poorly absorbed ${ }^{45}$. The MlogP, S+logP, S+logD values, and the number of hydrogen bond donors of all compounds were less than 5 , indicating that they were hydrophilic in nature as well as they could be absorbed and excreted easily.

Table 3: Pharmacokinetic proprieties of Remdesivir and its derivatives obtained from MedChem Designer Software.

\begin{tabular}{lccccc}
\hline \multirow{2}{*}{ Compounds } & \multicolumn{5}{c}{ Pharmacokinetic Parameters } \\
\cline { 2 - 5 } & MWt & MlogP & S+logP & S+logD & HBDH \\
\cline { 5 - 6 } Remdesivir & 602.588 & 0.634 & 1.597 & 1.597 & 5.000 \\
D-CF $_{3}$ & 655.572 & 1.424 & 2.905 & 2.905 & 3.000 \\
D-C $_{\mathbf{2}} \mathbf{H}_{\mathbf{5}}$ & 615.627 & 1.059 & 2.255 & 2.255 & 3.000 \\
D-F & 605.564 & 1.033 & 2.413 & 2.413 & 3.000 \\
D-I & 713.469 & 1.327 & 2.678 & 2.678 & 3.000 \\
D-CH & 601.600 & 0.864 & 2.069 & 2.069 & 3.000 \\
D-OH & 603.573 & 0.634 & 1.611 & 1.581 & 4.000 \\
\hline
\end{tabular}

\section{Conclusion}

In this study, we have shown the non-bond interactions and binding affinity of Remdesivir and designed drugs against target receptor 7BTF for inhibiting SARS-CoV-2. All the modifiers (except D-F) predict more significant binding energy and non-bond interactions than the parent drug. The strongest binding affinity is found for D-I and 7BTF complex. Enhanced hydrogen bonding between the designed drugs and 7BTF has a significant contribution to higher binding affinity. Modified drugs also show better pharmacokinetic activity than Remdesivir. From our computational study, we can conclude that D-I is the best compound to treat COVID-19 disease. 


\section{Acknowledgment}

We are grateful to department of Biochemistry and Molecular Biology, Bangabandhu Sheikh Mujibur Rahman Science and Technology University for providing us the computational platform to complete the project.

\section{References}

1. Tang X, Wu C, Li X, et al. On the origin and continuing evolution of SARS-CoV-2. Natl Sci Rev. 2020;7(6):1012-1023. doi:10.1093/nsr/nwaa036

2. Wu D, Wu T, Liu Q, Yang Z. The SARS-CoV-2 outbreak: What we know. Int J Infect Dis. Published online 2020. doi:10.1016/j.ijid.2020.03.004

3. Hendaus MA. Remdesivir in the treatment of coronavirus disease 2019 (COVID-19): a simplified summary. J Biomol Struct Dyn. Published online May 20, 2020:1-6. doi:10.1080/07391102.2020.1767691

4. Grein J, Ohmagari N, Shin D, et al. Compassionate use of remdesivir for patients with severe Covid-19. N Engl J Med. Published online 2020. doi:10.1056/NEJMoa2007016

5. Xu L, Liu J, Lu M, Yang D, Zheng X. Liver injury during highly pathogenic human coronavirus infections. Liver Int. 2020;40(5):998-1004. doi:10.1111/liv.14435

6. Su S, Wong G, Shi W, et al. Epidemiology, Genetic Recombination, and Pathogenesis of Coronaviruses. Trends Microbiol. 2016;24(6):490-502. doi:10.1016/j.tim.2016.03.003

7. Li X, Geng M, Peng Y, Meng L, Lu S. Molecular immune pathogenesis and diagnosis of COVID19. J Pharm Anal. 2020;10(2):102-108. doi:10.1016/j.jpha.2020.03.001

8. Tan YJ, Lim SG, Hong W. Characterization of viral proteins encoded by the SARS-coronavirus genome. Antiviral Res. 2005;65(2):69-78. doi:10.1016/j.antiviral.2004.10.001

9. Gao Y, Yan L, Huang Y, et al. Structure of the RNA-dependent RNA polymerase from COVID19 virus. Science (80- ). 2020;368(6492):779-782. doi:10.1126/science.abb7498

10. Choy KT, Wong AYL, Kaewpreedee P, et al. Remdesivir, lopinavir, emetine, and homoharringtonine inhibit SARS-CoV-2 replication in vitro. Antiviral Res. 2020;178:104786. doi:10.1016/j.antiviral.2020.104786

11. Wang Y, Zhang D, Du G, et al. Remdesivir in adults with severe COVID-19: a randomised, double-blind, placebo-controlled, multicentre trial. Lancet. Published online 2020. doi:10.1016/S0140-6736(20)31022-9

12. Al-Tawfiq JA, Al-Homoud AH, Memish ZA. Remdesivir as a possible therapeutic option for the COVID-19. Travel Med Infect Dis. Published online 2020. doi:10.1016/j.tmaid.2020.101615 
13. Pizzorno A, Padey B, Julien T, et al. Characterization and Treatment of SARS-CoV-2 in Nasal and Bronchial Human Airway Epithelia. Cell Reports Med. Published online 2020. doi:10.1016/j.xcrm.2020.100059

14. Gordon CJ, Tchesnokov EP, Woolner E, et al. Remdesivir is a direct-acting antiviral that inhibits RNA-dependent RNA polymerase from severe acute respiratory syndrome coronavirus 2 with high potency. J Biol Chem. Published online 2020. doi:10.1074/jbc.RA120.013679

15. Glennon JD. MOLECULAR RECOGNITION TECHNOLOGY, IN INORGANIC EXTRACTION. In: Encyclopedia of Separation Science. ; 2000. doi:10.1016/b0-12-2267702/02051-2

16. Shawon J, Khan AM, Rahman A, et al. Molecular Recognition of Azelaic Acid and Related Molecules with DNA Polymerase I Investigated by Molecular Modeling Calculations. Interdiscip Sci Comput Life Sci. Published online 2018. doi:10.1007/s12539-016-0186-3

17. Berry M, Fielding B, Gamieldien J. Practical Considerations in Virtual Screening and Molecular Docking. In: Emerging Trends in Computational Biology, Bioinformatics, and Systems Biology: Algorithms and Software Tools. Elsevier Inc.; 2015:487-502. doi:10.1016/B978-0-12-8025086.00027-2

18. Krusemark CJ. Drug Design: Structure- and Ligand-Based Approaches. Q Rev Biol. Published online 2012. doi:10.1086/665453

19. Remdesivir | C27H35N6O8P - PubChem. Accessed August 19, 2020. https://pubchem.ncbi.nlm.nih.gov/compound/121304016\#section=2D-Structure

20. RCSB PDB - 7BTF: SARS-CoV-2 RNA-dependent RNA polymerase in complex with cofactors in reduced condition. Accessed August 19, 2020. https://www.rcsb.org/structure/7BTF

21. Lill MA, Danielson ML. Computer-aided drug design platform using PyMOL. J Comput Aided Mol Des. Published online 2011. doi:10.1007/s10822-010-9395-8

22. Guex N, Peitsch MC, Schwede T. Automated comparative protein structure modeling with SWISS-MODEL and Swiss-PdbViewer: A historical perspective. Electrophoresis. Published online 2009. doi:10.1002/elps.200900140

23. Morris GM, Lim-Wilby M. Molecular docking. Methods Mol Biol. 2008;443:365-382. doi:10.1007/978-1-59745-177-2_19

24. RA L, MB S. LigPlot+: multiple ligand-protein interaction diagrams for drug discovery. J Chem Inf Model. Published online 2011.

25. Trott oleg, Arthur J. Olson. AutoDock Vina: Improving the Speed and Accuracy of Docking with a New Scoring Function, Efficient Optimization, and Multithreading. J Comput Chem. Published online 2010. doi:10.1002/jcc

26. Miyata T. Discovery studio modeling environment. Ensemble. Published online 2015. 
27. Dar AM, Mir S. Molecular Docking: Approaches, Types, Applications and Basic Challenges. $J$ Anal Bioanal Tech. Published online 2017. doi:10.4172/2155-9872.1000356

28. Cheng F, Li W, Zhou Y, et al. AdmetSAR: A comprehensive source and free tool for assessment of chemical ADMET properties. J Chem Inf Model. 2012;52(11):3099-3105.

doi:10.1021/ci300367a

29. Pal GK. Endocrine Physiology. Textb Med Physiol Ahuja Publ House, India2007. 2007;346.

30. Furuya T, Kamlet AS, Ritter T. Catalysis for fluorination and trifluoromethylation. Nature. Published online 2011. doi:10.1038/nature10108

31. McClinton MA, McClinton DA. Trifluoromethylations and related reactions in organic chemistry. Tetrahedron. 1992;48(32):6555-6666. doi:10.1016/S0040-4020(01)80011-9

32. Lishchynskyi A, Novikov MA, Martin E, Escudero-Adán EC, Novák P, Grushin V V. Trifluoromethylation of aryl and heteroaryl halides with fluoroform-derived CuCF3: Scope, limitations, and mechanistic features. J Org Chem. Published online 2013. doi:10.1021/jo401423h

33. Sarwar MG, Dragisic B, Salsberg LJ, Gouliaras C, Taylor MS. Thermodynamics of halogen bonding in solution: Substituent, structural, and solvent effects. J Am Chem Soc. Published online 2010. doi:10.1021/ja9086352

34. Wade RC, Goodford PJ. The role of hydrogen-bonds in drug binding. Prog Clin Biol Res. Published online 1989.

35. Chen D, Oezguen N, Urvil P, Ferguson C, Dann SM, Savidge TC. Regulation of protein-ligand binding affinity by hydrogen bond pairing. Sci Adv. 2016;2(3):e1501240.

doi:10.1126/sciadv.1501240

36. Israelachvili J, Pashley R. The hydrophobic interaction is long range, decaying exponentially with distance. Nature. 1982;300(5890):341-342. doi:10.1038/300341a0

37. Pang KS. Modeling of intestinal drug absorption: Roles of transporters and metabolic enzymes (for the gillette review series). Drug Metab Dispos. Published online 2003. doi:10.1124/dmd.31.12.1507

38. Yamashita S, Furubayashi T, Kataoka M, Sakane T, Sezaki H, Tokuda H. Optimized conditions for prediction of intestinal drug permeability using Caco-2 cells. Eur J Pharm Sci. Published online 2000. doi:10.1016/S0928-0987(00)00076-2

39. Tanigawara Y. Role of P-glycoprotein in drug disposition. Ther Drug Monit. Published online 2000. doi:10.1097/00007691-200002000-00029

40. Huang X-P, Mangano T, Hufeisen S, Setola V, Roth BL. Identification of Human Ether-à-go-go Related Gene Modulators by Three Screening Platforms in an Academic Drug-Discovery Setting. Assay Drug Dev Technol. 2010;8(6):727-742. doi:10.1089/adt.2010.0331

41. Kubinyi H. Lipophilicity and drug activity. Prog Drug Res. 1979;23:97-198. doi:10.1007/978-30348-7105-1_5 
42. Khera A V., Cuchel M, De La Llera-Moya M, et al. Cholesterol efflux capacity, high-density lipoprotein function, and atherosclerosis. N Engl J Med. Published online 2011. doi:10.1056/NEJMoa1001689

43. Rout S, Mahapatra RK. In silico screening of novel inhibitors of M17 Leucine Amino Peptidase (LAP) of Plasmodium vivax as therapeutic candidate. Biomed Pharmacother. Published online 2016. doi:10.1016/j.biopha.2016.04.057

44. Lipinski CA, Lombardo F, Dominy BW, Feeney PJ. Experimental and computational approaches to estimate solubility and permeability in drug discovery and development settings. Adv Drug Deliv Rev. Published online 2012. doi:10.1016/j.addr.2012.09.019

45. C.G.WermuthP.CiapettiB.GiethlenP.Bazzini. Bioisosterism. Elsevier; 2007. doi:10.1016/B0-08045044-X/00051-1 